\title{
CBS (Coğrafi Bilgi Sistemleri) Teknikleri Kullanılarak Muş İlinin Bazı Toprak Özelliklerinin Genel Değerlendirmesi*
}

\section{General Evaluation of Some Soil Characteristics of the Mus Province Using GIS (Geographical Information System) Technique}

\author{
Mustafa Yaşar ${ }^{\text {a }}{ }^{* *}$, Yavuz Şahin Turgut $^{\mathrm{b}}$, Yakup Kenan Koca ${ }^{\mathrm{c}}$ \\ ${ }^{a}$ Dr. Öğr. Üyesi, Muş Alparslan Üniversitesi Uygulamalı Bilimler Fakültesi Bitkisel Üretim ve Teknolojileri Bölümü, Muş/Türkiye. \\ ORCID: 0000-0001-9348-7978 \\ b Ar. Gör., Çukurova Üniversitesi Ziraat Fakültesi Toprak Bilimi ve Bitki Besleme Bölümü, Adana/Türkiye. \\ ORCID: 0000-0002-8566-6375 \\ ${ }^{\mathrm{c}}$ Doç. Dr. Çukurova Üniversitesi Ziraat Fakültesi Toprak Bilimi ve Bitki Besleme Bölümü, Adana/Türkiye. \\ ORCID: 0000-0001-9285-1416
}

\section{MAKALE BİLGİSİ \\ Makale Geçmişi: \\ Başvuru Tarihi: 26 Kasım 2020 \\ Düzeltme Tarihi: 16 Aralık 2020 \\ Kabul Tarihi: 20 Aralık 2020}

\section{Anahtar Kelimeler:}

Muş İli

Tarımsal Verimlilik

Coğrafi Bilgi Sistemleri

Muş Ovası

\section{ARTICLE INFO}

Article history:

Received 26 November 2020

Received in revised form 16 December 2020

Accepted 20 December 2020

\section{Keywords:}

Mus Province

Agricultural Productivity

Geographic Information System

Mus Plain
ÖZ

Bu çalışmada Muş ilinin bazı toprak özelliklerinin CBS (Coğrafi Bilgi Sistemleri) teknikleriyle genel bir değerlendirmesinin yapılması amaçlanmıştır. Çalışma kapsamında, mülga Köy Hizmetleri Genel Müdürlüğü tarafından hazırlanmış olan "Muş İli Verimlilik Envanteri ve Gübre İhtiyaç Raporu" ve "1/100.000 ölçekli Verimlilik Haritaları" kullanılmıştır. Buna göre Muş ili toprakları göre genel olarak killi ve killi balçık tekstür ve genellikle de nötr $\mathrm{pH}$ özellikleri göstermekte olup, tuzluluk sorunları da çok düşük düzeydedir.Ayrıca sahadaki topraklarının tarımsal verimlilik düzeylerinin düşük, orta ve yüksek olduğu ortaya çıkarılmıştır. Bu çalışmanın Muş ilindeki toprakları konusundaki mevcut çalışmaların modern yöntem ve tekniklerle tekrar ele alınıp değerlendirilmesinin önemini yansıtması bakımından literatürde önemli bir boşluğu dolduracağı düşünülmektedir. Ayrıca bu çalışmanın Türkiye'nin diğer illerinde bu konuda benzer araştırmalara örnek teşkil edeceği tahmin edilmektedir.

\section{A B S T R AC T}

In this study, it has been aimed to perform an assessment of some soil characteristics of Mus Province by GIS (Georaphical Information System) methods. In this context, it has been utilized from the "Mus Province Productivity Inventory and Fertilizer Needs Report", which was prepared by the General Directorate of Rural Services and contained 1/100.000 scale productivity map. . Accordingly, it has been determined the soils of Muş province was generally clayey and clayey loam texture and showed neutral $\mathrm{pH}$ characteristics, as well as salinity was also quite low. Besides this, it has been detected the levels of agricultural productivity was low, medium and high,respectively. It is thought that this study will fill an important gap in the literature as it reflects the importance of reconsidering and evaluating the existing studies on the lands in Mus province with modern methods and techniques. Furthermore, the study are also expected to serve as a model for similar research on this subject in Turkey's other provinces.

\section{Giriş}

Belirli bir bölgedeki toprak oluşumu, o bölgedeki iklim ve canlıların değişik topoğrafik koşullar ve belirli bir süreç içerisinde ana madde üzerinde etkisinin bir fonksiyonudur (Jenny, 1941). Ayrıca belirtilen bu beş faktörle birlikte söz konusu toprakların profillerinde meydana gelen ayrışma, taşınma, yıkanma, birikme ve yer değiştirme gibi toprak

* Bu çalışma, 22-23 Ekim 2020 tarihlerinde Muş Alparslan Üniversitesinde düzenlenen II. Uluslararası Muş Sempozyumunda sözlü bildiri olarak sunulmuştur.

** Sorumlu yazar/Corresponding author.

e-posta: mustafa.yasar@alparslan.edu.tr 
yapan olaylarda meydana gelen fiziksel, kimyasal ve biyolojik reaksiyonlarla topraklar kendilerine özgü karakter kazanırlar. Bu değişimler zaman etkisinin önemini ortaya koymaktadır. Zaman içerisinde profilde meydana gelen bu değişimler topraklarında çeşitlenmesine etkili olmaktadır (Usul ve Dengiz, 2010)

Deniz seviyesinden 1.350 metre yüksekte bulunan Muş ili Doğu Anadolu Bölgesi'nin orta-güney bölümünde yer almaktadır. Diyarbakır, Batman, Bitlis, Ağrı, Erzurum ve Bingöl illeri ile çevrili olan ilin toplam arazisinin \%34'ü ovadır. Muş'un en büyük ovası olan ve ilin adı ile anılan söz konusu ova, 1.650 km2'lik bir sahayı kapsamaktadır ve Türkiye'nin üçüncü büyük ovası olarak kabul edilmektedir. Genç ve verimli alüvyonlarla örtülü olan il sınırları içinde Haçl1, Büyük Hamurpet, Küçük Hamurpet ve Kaz Gölleri ile uzunluğu $600 \mathrm{~km}$ olan Murat ırmağı ve uzunluğu $68 \mathrm{~km}$ olan Karasu ırmağı bulunmaktadır. İlin toplam yüzölçümü 8.196 km2'dir. Orta Fırat havzası içinde yer alan İlin $\% 42$ 'si tarım alanı, \%46'sı çayır-mera, \%7'si orman ve \%5'i tarım dışı arazi olarak sınıflandırılmıştır. İlde etkin ve verimli tarımsal üretime izin veren I-IV. sınıf tarım arazilerinin toplamı 365.703 ha'dır (Anonim, 2020b).

İlin toplam nüfusu 407.992 olup \%80’i tarımla iştigal etmektedir. Toplam nüfusun \%56'sı kırsalda yaşamaktadır.

İlin 4 büyük ovası Muş, Bulanık, Malazgirt ve Liz Ovası mevcut olup, toplam alanı 278.000 ha'dır. Muş ovası Türkiye'nin tek parça 165.000 ha. ile 3. büyük ovasıdır ve 2017 yılında Bakanlar Kurulu kararı ile büyük ova koruma alanı olarak ilan edilmiştir (Anonim, 2020b).

Muş ovası, Türkiye'nin en büyük ovalarından birisi olmasına ve yeterli su kaynaklarına sahip olmasına rağmen ovadan yeterince faydalanılamamıştır. İl'in su kaynakları (akarsu, gölet, baraj gölleri v.b) Türkiye ortalamasının üzerindedir. Yerüstü su potansiyeli $4,505.93 \mathrm{hm}^{3} /$ y1l ve yer altı su potansiyeli $117 \mathrm{hm}^{3} /$ yıl olmak üzere toplam su potansiyeli $4,622.93 \mathrm{hm}^{3} /$ y1l'dır. İlin en önemli akarsu kaynakları dönem dönem taşkın ve sel riskini de beraberinde getirmektedir. 1963. 2003, 2004, 2011 ve 2012 yıllarında yaşanan sel ve taşkın olayları ciddi zararlar meydana getirmiş, en büyük zararı da Muş Ovası'nın alçak yerlerinde oluştuğu bildirilmiştir (Dölek, 2013; Günek ve ark., 2013)

Mevcut verilere göre, İlde toplam 344.842 ha tarım arazisinin 162.165 ha'11 (\%47'si) sulanabilir yapıdadir. Ancak arazinin sadece 72.171 ha' lık kısmı fiilen halk ve devletin imkanları ile sulanmaktadır. $\mathrm{Bu}$ alan sulanabilir tarım arazisinin \%44,5'ini oluşturmaktadır. Geriye kalan sulanabilen arazinin $\% 55,5^{\prime} \mathrm{i}$ sulanamamaktadır. Ancak inşaatına başlanan Alparslan-II Barajı ve Muş Ovası Sulama Projesinin bitmesi ile beraber Muş Ovasının 78.210 ha '1 (sulanacak tarım arazisi \%49,43'a çıkacaktır) sulanacaktır. (Anonim, 2020b).

$\mathrm{Bu}$ çalışmada mülga Köy Hizmetleri Genel Müdürlüğü tarafindan hazırlanmış olan "Muş İli Verimlilik Envanteri ve Gübre İhtiyaç Raporu” ve raporda yer alan “1/100.000 ölçekli Verimlilik Haritaları"nın CBS teknikleriyle genel bir değerlendirmesi yapılmıştır. Sayısal ortamda elde edilen haritalar ileriki çalışmalarda benzer ve farklı disiplinlerde de kullanılmak üzere kullanıcılara sunulmuştur.

\section{Materyal ve Metot}

\subsection{Materyal}

Muş ili, Doğu Anadolu Bölgesi'nin Yukarı Murat-Van Bölümü'nde yer almaktadır. Muş, doğudan Ağrı'nın Patnos ve Tutak, Bitlis'in Ahlat ve Adilcevaz, kuzeyden Erzurum'un Karayazı, Hınıs, Tekman, Karaçoban, batıdan Bingöl'ün Karlıova ve Solhan, güneyden ise Diyarbakır'ın Kulp, Batman'ın Sason ve Bitlis'in Güroymak ve Mutki ilçeleri ile çevrilidir (Dölek ve ark., 2018; Anonim 2020a) (Şekil 1).

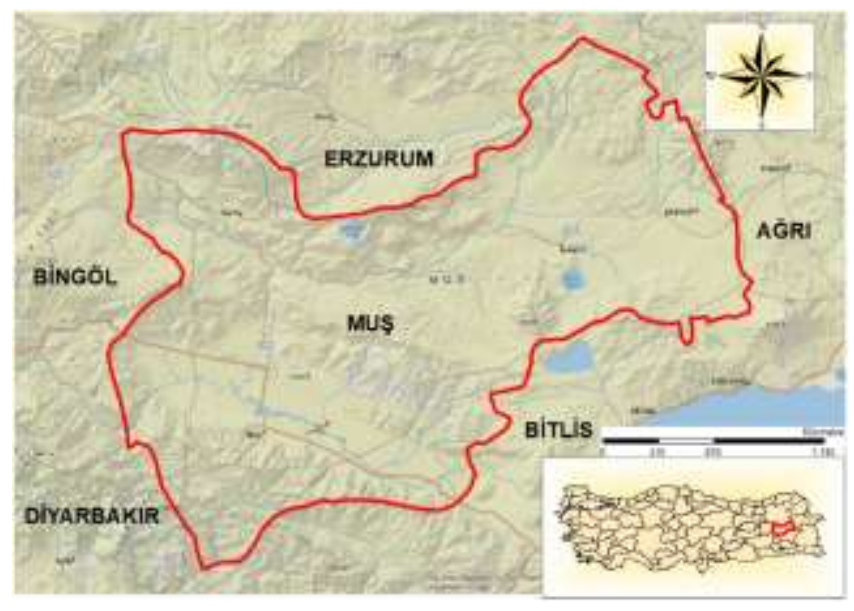

Şekil 1. Muş ili lokasyon haritası

Muş yüksek ve dağlık bir yörededir. İl alanının \%34,9'unu kaplayan dağlar, Güney Doğu Torosların uzantılarıdır. Bu dağlar, Alp-Himalaya kıvrım sistemiyle birlikte oluşmuş genç dağlardır. Rakım, genellikle 1.250 metrenin üzerindedir. Güneydoğu Toros Dağları'nın uzantıları Muş il alanını çevreler. Muş ilinin başlıca önemli dağları Akdoğan (Hamurpet), Şerafettin, Bilican, Bingöl, Haçreş (Karaçavuş, Çavuş), Otluk ve Yakupağa dağlarıdır. Buna karşın, yaklaşık 278.000 ha alana sahip dört büyük ova (Muş, Bulanık, Malazgirt ve Liz Ovaları) ilin tarımsal potansiyele sahip önemli düzlükleridir. Etrafi Nemrut, Şerafettin, Kurtik ve Narcoş Dağları gibi yüksek dağlarlar çevrili olan Muş Ovası yaklaşık 165.000 ha alana sahiptir. (Dölek, 2013). Muş ilindeki vadiler Murat Irmağı ve kollarınca açılmıştır. Muş ilinde dağlar, platolar, ovalar ana yer şekillerini oluşturmaktadır. Bu yerşekillerinin önemli bir kısmını oluşturan dağlar çoğu yerde dar ve derin vadiler tarafından parçalanmış, ovalar ise bu akarsuların taşkın yatakları haline gelmiştir. Bu vadilerin en önemlisi Murat Vadisidir. İlin en önemli sulama kaynakları Murat, Karasu, Alican ve Bulbulak Nehirleri'dir. Bunun yanı sıra; Hünan, Haçlı, Hartuaz, Taksih, Hınıs (Kocasu) Çayı, Bağdişan Çayı, Körsu Deresi, Kesik Çayı ve Şekerbulak Deresi'dir (Kıranşan, 2017). Bu derelerin il genelinde sel taşkın yapma riskleri de bulunmaktadır. Buna yönelik Dölek ve Avcı (2017) tarafından yapılan çalışmada, ilin sele duyarlılığının $\% 21$ orta ve $\% 48$ yüksek düzeyde olduğunu belirlenmiştir. Muş ili sınırları içinde kalan başlıca göller: Haçlı (Bulanık), Hamurpet (Akdogan), Küçük Hamurpet, Gaz (Kaz) gölleridir (Anonim 2020b). (Şekil 2) 


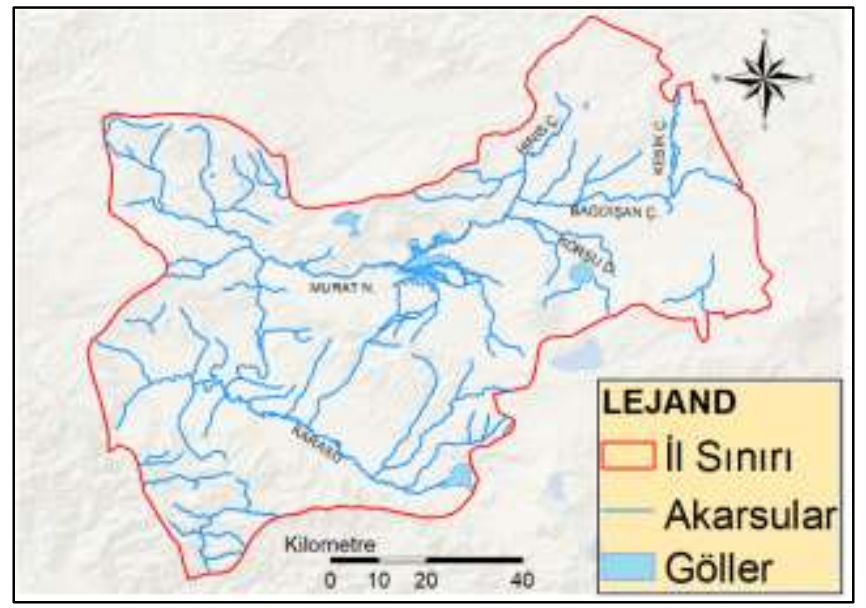

Şekil 2. Muş ili su kaynakları haritası

CORINE verileri ilin genel arazi kullanımı ile ilgili önemli veri barındımaktadır. Muş ilinin arazi örtüsü dağılımını belirlemek amacıyla Avrupa Çevre Ajansı'na ait 2018 yılı CORINE arazi örtüsü verileri kullanılmıştır (CLC,2018). Arazi örtüsü/kullanımı, sanayi-yerleşim-maden, tarım alanları, seyrek bitki örtüsü, su kaynakları, orman ve meralar-doğal alanlar olarak sınıflandırılmıştır. Bu sinıflandirma sonucu, tarım alanları 274.633 ha, meralar ve doğal alanlar 221.164 ha, seyrek bitki örtüsü bulunan alanlar 116.112 ha, orman alanları 70.489 ha, Su kaynakları 20.123 ha, Sanayi-Yerleşim-Maden sahaları 11.533 ha olarak belirlenmiştir (Şekil 3).

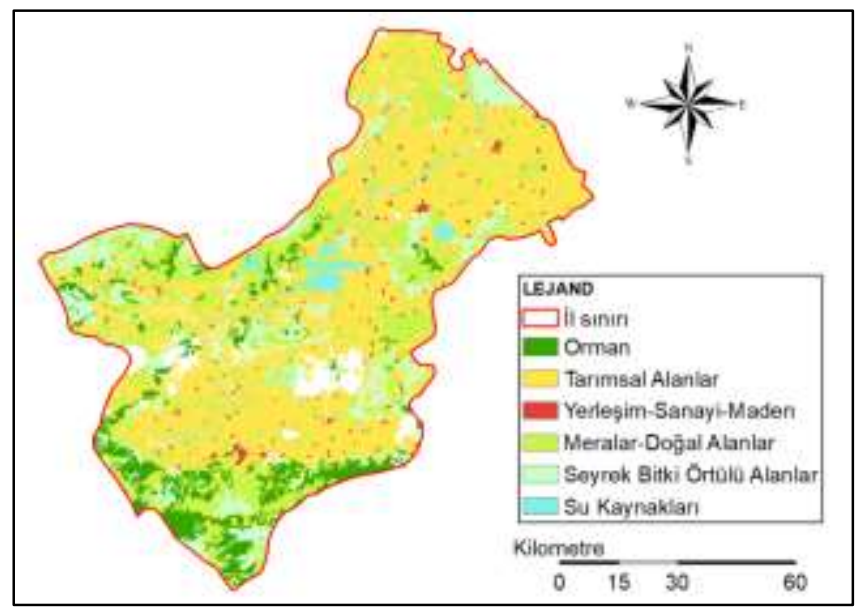

Şekil 3. Muş ili CORINE arazi örtüsü/kullanımı haritası

Önemli geçim kaynakları içerisinde tarımın ilk sırada yer aldığı Muş ilinde tarla tarımı önemli yer tutmaktadır. İlde Tarla tarımı alanı 206.745 ha, sebze tarımı alanı 4.131 ha, baharat bitkileri tarımı alanı 1.331 ha ve nadas alanı 26.139 ha'dır (TÜİK, 2019). Tarla tarımı içerisinde buğday, arpa ve yem bitkilerinden yonca önemli yer tutmaktadır. Sebze bitkilerinden ise karpuz, domates ve lahana önemli ekiliş alanlarına sahiptir.

Çalışmada 1988 yılında (mülga) Tarım Orman ve Köyişleri Bakanlığı Köy Hizmetleri Genel Müdürlüğü tarafindan yapılmış olan "Muş İli Verimlilik Envanteri ve Gübre İhtiyaç Raporu" (Anonim, 1988) ve raporun sonunda yer alan haritalar kullanılmıştır. Haritaların gerçek coğrafi konumlarına yerleştirilmesi ve sonrasında sayısallaştırılması aşamasında ArcGIS programından yararlanılmıştır.
Raporda yer alan toprak analizleri değerlendirme ölçü ve standartları kullanılmıştır. $\mathrm{Bu}$ standartlara göre toprak pH'sının değerlendirmesinde saturasyon çamurunda cam elektrod ile belirlenen ölçünün, 4,5'dan küçük olması durumunda kuvvetli asit, 4,5-5,5 orta dereceli asit, 5,5-6,5 hafif dereceli asit, 6,5-7,5 nötr, 7,5-8,5 hafif alkali ve 8,5'dan yüksek ise kuvvetli alkali olarak tanımlanmıştır. Tuz değerlerine bakıldığında ise saturasyon çamurunda elektriki geçirgenlik 0,15 'den küçük ise tuzsuz, 0,15-0,35 hafif tuzlu, 0,35-0,65 orta tuzlu ve 0,65 'den yüksek ise çok tuzlu olarak tanımlanmıştır.

\subsection{Metod}

Çalışmada 1988 yılında (Mülga) Tarım Orman ve Köyişleri Bakanlığı Köy Hizmetleri Genel Müdürlüğü tarafından yapılmış olan "Muş İli Verimlilik Envanteri ve Gübre İhtiyaç Raporu" nda yer alan haritalar taratıldıktan sonra ArcGIS ortamında coğrafi düzelmeleri yapılarak sayısallaştırılmıştır. Harita içerisinde yer alan ve harita lejantında açıklamaları bulunan tüm bilgiler öznitelik tablosuna işlenmiştir. $\mathrm{Bu}$ raporda, büyük toprak grubu (BTG), eğim, derinlik, bünye, taşlılık v.b toprak özellikleri verilmiştir. Ayrıca azot $(\mathrm{N})$, alınabilir fosfor $\left(\mathrm{P}_{2} \mathrm{O}_{5}\right)$ ve alınabilir potasyum $\left(\mathrm{K}_{2} \mathrm{O}\right)$ değerleri de verilmiştir. $\mathrm{Bu}$ değerlendirmede Toprak Analizleri değerlendirme ölçü ve standartları kullanılmıştır. $\mathrm{Bu}$ standarda göre belirlenen değerler haritalanmıştır. Haritalarda azot 0-2 arasında az, 23 arasında orta ve 3ten yüksek ise yüksek olarak sınıflandırılmıştır. Fosfor düzeyi 0-5 arasında az, 6-9 arasında orta ve 9'dan yüksek ise yüksek olarak sınıflandırmıştır. Potasyum düzeyleri ise 0-20 arasında az, 20-30 arasında orta ve 30'dan yüksek ise yüksek olarak sınıflandırılmıştır. Eğim düzeylerine yönelik sınıflamada ise eğim \%0-2 ise düz-düze yakın, $\% 2-6$ arasında ise hafif eğimli, \%6-12 arasında ise orta eğimli, \%12-20 arasında ise dik eğimli, \%20-30 arasında ise çok dik ve \%30'dan fazla ise sarp olarak tanımlanmıştır. Raporda yer alan her veriye ait alan hesaplamaları yapılmıştır ve çeşitli tematik haritalar üretilmiştir.

\section{Bulgular}

\subsection{Muş İli Toprakları}

Muş ilinde BTG (Büyük Toprak Grubu) düzeyinde; KT (Kestanerengi Topraklar), VT (Vertisoller), AT (Alüvyal Topraklar), KKT (Kireçsiz Kahverengi Topraklar), KO (Kolüvyal Topraklar), BT (Bazaltik Topraklar), R (Regosoller) ve KKO (Kireçsiz Kahverengi Orman Toprakları) bulunmaktadır (Şekil 4). 


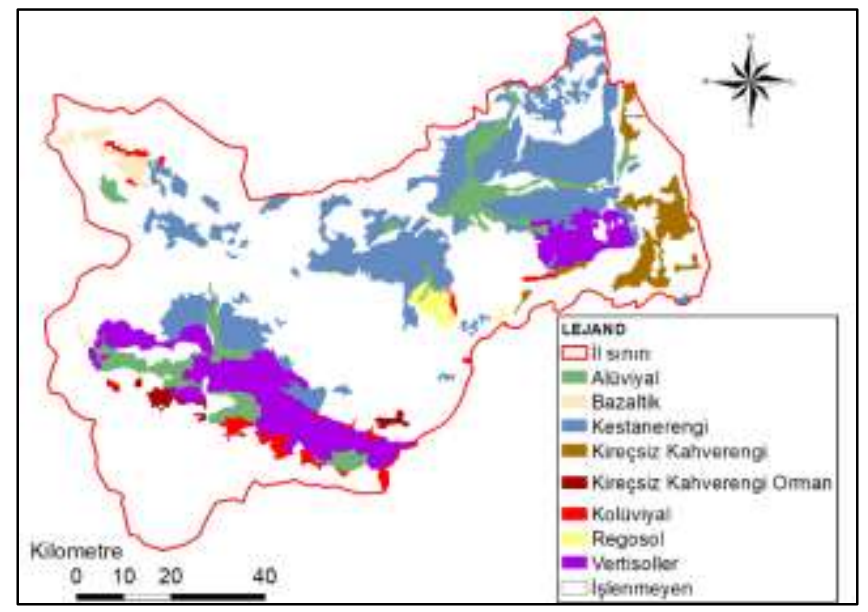

Şekil 4. Muş ili Büyük Toprak Grubu (BTG) haritası

Tablo 1. Muş ili Büyük Toprak Gruplarının (BTG) kapladıkları alanlar

\begin{tabular}{lcc}
\multicolumn{1}{c}{ BTG } & \multicolumn{2}{c}{ hlan } \\
\cline { 2 - 3 } & & $\%$ \\
\hline Vertisoller & 65.526 & 7,53 \\
\hline Alüviyaller & 43.078 & 4,95 \\
\hline Bazaltik Topraklar & 6.937 & 0,80 \\
\hline $\begin{array}{l}\text { Kestanerengi } \\
\text { Topraklar }\end{array}$ & 134.173 & 15,41 \\
\hline $\begin{array}{l}\text { Kireçsiz Kahverengi } \\
\text { Topraklar }\end{array}$ & 19.423 \\
\hline $\begin{array}{l}\text { Kireçsiz Kahverengi } \\
\text { Orman Toprakları }\end{array}$ & 4.329 & 2,23 \\
\hline Kolüviyaller & 9.889 & 0,50 \\
\hline Regosoller & 5.345 & 1,14 \\
\hline İşlenmeyen & 582.065 & 0,61 \\
\hline Toplam & 870.768 & 100,00 \\
\hline
\end{tabular}

\section{Kestanerengi Topraklar (KT)}

İl toplam toprak varlığ topraklardır. Yaklaşık 134.173 ha alan ile çalışma alanın yaklaşı1k \%15.41'inde dağılım göstermiştir. Eğim bakımından çok farklı eğim sınıflarına sahiptir. En fazla $\mathrm{C}$ eğimine $(\% 55,3)$ sahipken, $G(\% 0,27)$ eğimine sahip kestane rengi topraklar da bulunmaktadır. Bununla birlikte çok az düzeyde de olsa Litozolik (dik eğimli ve sığ) topraklar da $(\% 0,31)$ görülmektedir. $\mathrm{Bu}$ toprakların, 111.732 dekarlık alanda (da) taşlılık $(\% 8,33)$ ve 8.184 da $(\% 0,61)$ hafif tuzluluk sorunu bulunmaktadir. $\mathrm{Bu}$ topraklarda drenaj problemi bulunmamaktadır. $\mathrm{Bu}$ toprakların erozyon düzeyine bakıldığında ise; yaklaşık $\%$ 68'inde (911.795 da) orta düzeyde, yaklaşık \%5'inde (62.613 da) şiddetli ve yaklaşık \%1'inde (12.625 da) çok şiddetli erozyon etkili olmaktadır. Buna karşın, bu toprakların \%26'sında (350.536 da) erozyon hiç veya çok az düzeyindedir. Raporun yayınlandığı yıla ait arazi kullanımları verilmiştir. Buna göre; çalışma alanın \%95'inde (127.504 da) nadaslı kuru tarım, yaklaşık \%4'ünde (47.689 da) sulu tarım yapılmaktadır. Besin elementi düzeyleri değerlendirildiğinde ise toprakların azot düzeyleri bakımından sırasıyla; $\% 38,5$ 'in az, $\% 43,6$ 's1 orta ve $\% 14,7$ 'si yüksek düzeydedir. Alınabilir fosfor düzeyleri bakımından sırasıyla; \%66'sı az, \%23'ü orta ve \%7,4'ü ise yüksek düzeydedir. Çalışma alanının hemen hemen tamamında ise $\mathrm{K}$ yüksek düzeydedir. Çalışma alanının \%3'ünde ise besin element düzeylerine yönelik herhangi bir bilgi bulunmamaktadır. KT'lerin pH düzeyi genellikle nötr ve nötr'e yakındır. Çalışma alanın \%80'i nötr, \%11'i hafif asidik ve \%8'i hafif alkalidir. Arazi yetenek sinıflamasına (AYS) göre; I. Sınıf araziler \%12, II. Sinıf araziler \%16,5, III. Sinıf araziler \%51,4, IV. Sinıf araziler \%12,7, VI. Sinıf araziler \%5,4 ve VII. Sinıf araziler ise \%1,5 dir. Arazi yetenek alt sınıfları değerlendirildiğinde ise arazilerin \%74,4'ünde eğim; \%13'ünde ise hem eğim hem de toprakla ilgili olumsuzluklar bulunmaktadır. \%12,4'ünde ise herhangi bir problem bulunmamaktadır. $\mathrm{Bu}$ toprakların bünye ve drenajı ile ilgili olarak raporda herhangi bir bilgi bulunmamaktadır.

\section{Vertisoller (VT)}

VT'ler il arazi varlığı verilerine göre KT'lerden sonra en fazla yayılım alanına sahip topraklardır. Yaklaşık olarak 65.526 ha'lık alan ile çalışma alanın \%7,5'inde dağılım göstermektedir. Eğim sınıfları bakımından üç farklı eğim sınıfina (A, B ve C) sahip topraklardır. En fazla eğim (591.324 da) \%90,5 ile A'da iken, en az eğim (2.802 da) $\% 0,5$ ile C'ye aittir. Çalışma alanın B eğimine sahip toprakların (61.137 da) oranı ise $\% 9,2$ dir. Toprak derinliği bakımından iki farklı derinlik sınıfi; orta ve derin topraklar yer almaktadır. Derin topraklar \%88 (576.068 da) ile VT'lerin büyük bir kısmını oluştururken, sı ğ toprakların oranı \%12 (79.195 da) dir. Toprakların \%45'i (296.750 da) hafif tuz karakterlidir. Çalışma alanının sadece \%1'i (3.671 da) yetersiz drenajlı /tuzlu alkali alanlar olarak tanımlanmıştır. Diğer özellikler açısından herhangi bir bilgi bulunmayan alanların oranı ise \%54 (353.146 da) tür. Erozyon sınıfları bakımından; alanın neredeyse tamamı hiç veya çok az erozyona uğramışken, yalnızca \%1'i (4.851 da) ise orta şiddetli erozyona maruz kalmıştır. Raporun yayınlandığı yıla ait arazi kullanımları verilmiştir. Buna göre; çalışma alanın \%92'inde (603.918 da) nadaslı kuru tarım, \%1'inde ( $8.678 \mathrm{da}$ ) sulu tarım yapılmaktadır. Rapora göre alanın \%7'sinde (42.667 da) ise arazi kullanımlarına ait bir bilgi bulunmamaktadır. Besin elementi düzeyleri değerlendirildiğinde ise toprakların azot düzeyleri bakımından sırasıyla; \%16,4'ü az, \%51,1'i orta ve $\% 31,3$ 'ü yüksek düzeydedir. Alınabilir fosfor düzeyleri bakımından sirasıyla; \%75,1'i az, \%21,1'i orta ve \%2,6's1 ise yüksek düzeydedir. VT'lerin hemen hemen tamaminda (\%99) ise $\mathrm{K}$ yüksek düzeydedir. $\mathrm{Bu}$ alanların \%1,2'sinde ise besin element düzeylerine yönelik herhangi bir bilgi bulunmamaktadır. VT'lerin \%39'u nötr, \%34'ü hafif asidik ve \%27'si ise hafif alkalidir. Arazi yetenek sinıflamasına (AYS) göre; alanın neredeyse tamamı II. Sınıf arazilerden oluşmaktadır. VT'lerin yaklaşık \%99'u II. Sınıf arazi olarak sınıflandırılmışken, III. Sınıf arazilerin oranı ise \%1'dir. Arazi yetenek alt sınıflarında ise alanın tamamı için sınırlayıcı faktör topraktır. Bu toprakların bünye ve drenajı ile ilgili olarak raporda herhangi bir bilgi bulunmamaktadır.

\section{Aluviyaller (AT)}

AT'ler il arazi varlığına göre çalışma alanında yer alan diğer BTG'lere göre \%5'lik (43.078 ha) bir alan 
kaplamaktadır. Bünye sınıfları bakımından en fazla \%60,1 (259.073 da) ile ince tekstürlü topraklar, en az \%5,7 (24.354 da) ile kaba tekstürlü topraklar bulunmaktadır. Orta tekstürlü toprakların oranı ise $\% 34,2$ (147.360 da) dir. Çalışma alanın drenaj koşulları bakımından; \%40,8'i (175.632 da) iyi, \%55,5 'i (238.967 da) yetersiz ve \%3,8'i (16.188 da) ise kötü drenajlıdır. Raporun yayınlandığı tarihteki arazi kullanım durumlarına bakıldığında en fazla kullanım türünün \%72,8 (313.404 da) ile nadaslı kuru tarıma ayrıldığ 1 ve \%24,2'sinin ise (104.107 da) sulu tarım için kullanıldığı görülmüştür. Raporda arazi kullanımlarına ilişkin herhangi bir bilgi bulunmayan alanların oranı ise $\% 3,1 \quad(13.275$ da) dir. Besin elementi düzeyleri değerlendirildiğinde, toprakların azot düzeyleri bakımından sırasıly; \%31,8'i az, \%44,7'si orta ve \%22,5'i yüksek düzeydedir. Alınabilir fosfor düzeyleri bakımından sırasılyla; \%56,5'i az, \%27,6'sı orta ve \%14,9'u ise yüksek düzeydedir. Çalışma alanın hemen hemen tamamında (\%98) ise $\mathrm{K}$ yüksek düzeydedir ve yalnızca \%0,8'i az düzeyindedir. Çalışma alanın \%1,1'inde ise besin element düzeylerine yönelik herhangi bir bilgi bulunmamaktadır. Toprakların $\mathrm{pH}$ düzeyleri bakımından en yüksek \%81,7 ile nötr ve en düşük \%3,8 ile hafif asidik $\mathrm{pH}$ seviyelerinde bulunduğu görülmektedir. Hafif alkali karakterde olanların oranı ise \%14,5 tir. Arazi yetenek sinıflamasına (AYS) göre; alanda \%54,2 ile II. Sınıf arazilerin en fazla dağılım gösterdiği ve bunu \%34 ile I. Sınıf arazilerin takip ettiği görülmektedir. Alandaki III. ve IV. Sınıf arazilerin oranı ise sırasıyla; \%5,5 ve \%6,3 olarak saptanmıştır. Arazi yetenek alt sınıflarında ise; arazilerin yarısında (\%50) su ile ilgili sıkıntılar bulunmaktadır. Toprak ve eğim bakımından olumsuzluklar saptanan toprakların oranı \%16 dir. Raporda arazi yetenek alt sinıfları bakımından herhangi bir bilgi verilmeyen alanların oranı ise \%34 tür. Ayrıca, raporda; eğim, toprak derinliği, erozyon ve diğer özellikler açısından herhangi bir bilgi bulunmamaktadır.

\section{Kireçsiz Kahverengi Topraklar (KKT)}

KKT'ler il arazi varlığı verilerine göre çalışma alanı içerisinde \%2,2'lik (19.423 ha) bir alan kaplamaktadır. Eğim sınıfları bakımından; en fazla eğim \%58 ile (112.542 da) B eğim sınıfinda görülürken, bunu \%36,4 (70.784 ha) ile $\mathrm{C}$ eğimi takip eder. $\mathrm{D}$ ve $\mathrm{F}$ eğim sınırlarının oranı ise sırasıyla; $(2.162 \mathrm{da}) \% 1,1$ ve $(8.743 \mathrm{da}) \% 4,5$ tir. Çalışma alanında yer alan topraklar genellikle orta derinliktedir. Orta derinliğe sahip toprakların oranı (137.224 da) $\% 70,5$ 'dir. Çok sığ ve derin toprakların alan içerisindeki dağılım oranları çok düşüktür. Çok sığ topraklar (7.629 da) yaklaşık \%4 ve derin topraklar $(8.743 \mathrm{da}) \% 4,5$ 'lik bir alan kaplamaktadır. Söz konusu alan içerisindeki sı̆̆ toprakların oranı ise (40.636 da) yaklaşık \%21 dir. Diğer özelliklere bakıldığında alanın neredeyse yarısının $(\% 47,8)$ taşlı olduğu ve geri kalan $(\% 52,2)$ k1sminda ise alana ait herhangi bir bilgi bulunmadığ alanın \%65,7'sinde (127.530 da) orta şiddetli erozyon görülmektedir. Şiddetli (142.045 da) veya çok şiddetli (7.629 da) erozyon görülen alanların oranı ise sırasıyla; $\% 7,3$ ve \%4'tür. Hiç veya çok az erozyon görülen alanların (44.870 da) oranı ise \%23'tür. Rapora göre alanın tamamında nadaslı kuru tarım yapılmaktadır. Besin elementi düzeyleri değerlendirildiğinde ise toprakların azot düzeyleri bakımından sırasıyla; $\% 42,4$ 'ü az, $\% 55,5$ 'i orta ve $\% 2,2$ 'si yüksek düzeydedir. Alınabilir fosfor düzeyleri bakımından sirasiyla; \%81,4'ü az ve \%18,6's1 orta düzeydedir. Çalışma alanın tamamında ise $\mathrm{K}$ yüksek düzeydedir. Toprakların $\mathrm{pH}$ düzeyleri $\% 55$ hafif alkali, $\% 43$ nötr ve $\% 2$ hafif asidiktir. AYS'ye göre; alanın neredeyse yarısı $(\% 49,3)$ III. Sınıf arazilerden oluşmaktadır. II. Sinıf araziler \%25,8, IV. Sinıf araziler \%13,6, VI. Sinıf araziler \%1.1 ve VII. Sinıf araziler \%10,1 dir. Arazi yetenek alt sınıfları bakımından; alanın \%42,5'inde eğim , $\% 23^{\prime}$ ünde toprak ve \%34,5' inde ise hem eğim hem de toprakla ilgili sorunlar vardır. Raporda bünye ve drenaj bakımından herhangi bir bilgi bulunmamaktadır.

\section{Kolüviyaller $(K O)$}

KO’lar, il arazi varlığı verilerine bağlı olarak çalışma alanı içerisinde \%1,1'lik (9.889 ha) bir alan kaplamaktadır. Eğim sınıfları bakımından; sırasıyla A eğimi (42.955 da) \%43,5 ; $\mathrm{B}$ eğimi ( $32.848 \mathrm{da}) \% 33,2$ ve $\mathrm{C}$ eğimi ise (23.091 da) $\% 23,3$ olarak belirlenmiştir. Toprak derinliklerinin oranı değişiklik göstermekle birlikte alanın (59.160 da) yaklaşık $\% 60$ '1 orta derinlikte topraklara sahiptir. Derin topraklar (29.023 da) yaklaşık olarak \%30 ve sı̆̆ topraklar (10.711 da) yaklaşık olarak \%11'lik bir alan kaplamaktadır. Alan içerisinde çok sı ğ derinlikte topraklar bulunmamaktadır. Bünye sinıflarına bakıldığında; orta bünyeye sahip toprakların (60.526 da) oranı \%61 dir ve en fazla dağılım gösteren bünye sınıfıdır. İnce bünyeli topraklar (27.115 da) $\% 27,5$ ve kaba bünyeli topraklar ise (11.253 da) \%11,5 dir. KO'lar içerisindeki taşlı arazilerin (1.590 da) oranı \%26,5; hafif tuzlu alkali toprakların (26.290 da) oranı ise \%1,5 tir. Raporda, diğer özellikler bakımından çalışma alanın geri kalanı ile ilgili herhangi bir bilgiye yer verilmemiştir. İlgili alanın \%50,3'ünde (49.746 da) hiç veya çok az, $\% 49,7$ 'sinde ise $(49.148 \mathrm{da})$ orta düzeyde erozyon görülmektedir. Çalışmanın yapıldığı tarihteki arazi kullanımının \%72,3'ünde (71.504 da) nadaslı kuru tarım yapılırken \%22'sinde (2.173 da) sulu tarım yapılmaktadır. Besin elementi düzeyleri değerlendirildiğinde ise; toprakların azot düzeyleri bakımından sırasıyla; \%27,3'ü az, $\% 58,1$ 'i orta ve $\% 14,7$ 'si yüksek düzeydedir. Alınabilir fosfor düzeyleri bakımından sirasıyla; \%34,2'si az ve $\% 63,8$ 'i orta ve $\% 2,1$ 'i yüksek düzeydedir. İlgili alanın tamamında ise $\mathrm{K}$ yüksek düzeydedir. $\mathrm{Bu}$ toprakların yaklaşık \%52'sinin $\mathrm{pH}$ 'sı hafif asidik, \%35,5'i nötr ve $\% 12,5$ 'i ise hafif alkali karakterdedir. AYS'ye göre; I. Sinıf araziler \%30,7 ; II.sinıf araziler \%20,4 , III. Sinıf araziler $\% 23,5$; IV. Sinıf araziler \%7,9, VI. Sinıf araziler \%10.6 ve VII. Sinıf arazilerin oranı \%6,9'dur. Arazi yetenek alt sınıfları bakımından; yalnızca eğim problemi olan araziler KO'ların \%18'ini oluşturmaktadır. Yalnızca toprak bakımından problemli olan araziler \%11 düzeyindedir. Hem eğim hem de toprak bakımından sorunlu araziler ise KO'ların \%38,3'ünü oluşturmaktadır. Hem toprak hem de drenaj bakımından problemli araziler ise KO'ların yalnızca \%2'sini oluşturmaktadır. Raporda drenaj ile ilgili herhangi bir bilgiye yer verilmemiştir.

\section{Bazaltik Topraklar (BT)}

BT'ler, il arazi varlığı verilerine bağlı olarak çalışma alanı içerisinde yer alan BTG'lere göre \%0.8'lik (6.937,37 ha) bir alan kaplamaktadır. Eğim yönünden BT'lerde D eğim \%43.2 (29.956 da) ile en fazla alanı kaplamaktadır. C eğim sınıfına giren toprakların oranı \%26 (18.034 da) ve F eğim 
sinıfinda yer alan toprakların oranı ise (15.109 da) \%21,8 dir. Eğim sınıfları arasında en az dağılıma sahip B eğiminin oranı ise $\% 9$ (6.274 da) dur. Derinlikleri bakımından değerlendirildiğinde; BT'lerin \%21,8'inin (15.109 da) çok si ğ, \%32,7’sinin (22 655 da) siğ, \%36.5'inin (25.334 da) orta ve \%9'unun (6274 da) derin olduğu görülmüştür. BT'lerin (44.719 da) \%64.5'i taşlı ve geri kalan (24.654 da) $\% .35 .5$ 'inde ise taşlılık sorunu yoktur. BT'ler erozyona maruz kalmaları açısından sırasıyla; hiç veya çok az erozyona uğrayan alanlar $(6.274 \mathrm{da}) \% 9$, orta şiddetli erozyona maruz kalanlar (26.709 da) \%38,5, şiddetli erozyona uğrayan alanlar $(21.280 \mathrm{da}) \% 30,7$ ve çok şiddetli erozyona maruz kalan alanların (15.109 da) oranı ise \%21,8 dir. Buna göre; BT'ler üzerinde yer alan alanların oranı yaklaşık \%63 (43.957 da) iken, ilgili alanların yaklaşık \%28'inde (19.234 da) sulu tarım yapılmaktadır. Arazi kullanımına ilişkin raporlamamış alanların oranı ise (6.182 da) yaklaşık \%9'dur. Besin elementi düzeyleri değerlendirildiğinde ise toprakların azot düzeyleri bakımından sirasıyla; \%11'i orta ve \%89'u yüksek düzeydedir. Alınabilir fosfor düzeyleri bakımından sirasıyla; \%72,3'ü az ve \%27,7'si orta düzeydedir. BT'lerin tamamında ise $\mathrm{K}$ yüksek düzeydedir. $\mathrm{Bu}$ toprakların yaklaşık \%24'ünün pH'sı nötr ve yaklaşık \%76'sının hafif asidik karakterdedir. AYS'ye göre; II. Sınıf araziler (6.274 da) \%9, III. sinıf araziler (13 748 da) \%19.8, IV. Sinıf araziler (12.961 da) \%18,7, VI. Sinıf araziler (21.281 da) $\% 30,7$ ve VII. Sinıf araziler (15.109 da) \%21,8'lik bir alan kaplamaktadır. Arazi yetenek alt sınıflarına göre; yalnızca eğim problemi olan topraklar BT'lerin \%18'ini oluşturmaktadır. Hem eğim hem de toprak yönünden sorunlu araziler BT'lerin \%82'sini oluşturmaktadır. Raporda bünye ve drenaj bilgisine yer verilmemiştir.

\section{Regosoller $(R)$}

R'ler, çalışma alanı içerisinde yer alan BTG'lere göre \%0,6'lık (5.345 ha) bir alan kaplamaktadır. Eğim yönünden R'lerde C eğimine sahip topraklar \%51(27.333 da) ile en fazla alanı kaplarken, bunu sırasıyla B eğimi \%42 (22.394 da) ve A eğimi \%7 (3.725 da) ile izlemektedir. R'lerin \%51'ini sığ topraklar (27.333 da) oluşturmaktadır. Orta derinlikteki (24.237 da) toprakların oranı \%45,3 ve derin toprakların (188 da) oranı ise \%3,5 dir. R'lerin \%51'i (27.333 da) şiddetli erozyona maruz kalmışken, yaklaşık \%38,5'i (20.512 da) hafif erozyona maruz kalmıştır. Hiç veya çok az erozyona maruz kalan alanların (5.608 da) oranı ise \%10,5 dir. Çalışmanın yapıldı ğı tarihte R olarak belirlenen alanların tamamında nadaslı kuru tarım yapılmaktadır. Besin elementi düzeyleri değerlendirildiğinde ise toprakların azot düzeyleri bakımından; \%93'ü orta ve \%7'si ise yetersiz düzeydedir. Alanın tamamında alınabilir fosfor yetersiz düzeyde iken, $\mathrm{K}$ ise yüksek düzeydedir. Bu toprakların tamamında $\mathrm{pH}$ nötr seviyesindedir. AYS'ye göre; II. Sınıf araziler \%10,5 (5.608 da), III. Sinıf araziler \%38.5 ve IV. Sinıf araziler ise $\% 51$ 'lik (27.333 da) bir alan kaplamaktır. Arazi yetenek alt sınıfları değerlendirildiğinde; sadece eğim problemli alanlar $\% 3$, sadece toprak ile ilgili sorunlu alanlar \% 7 ve hem eğim hem de toprak problemi bulunan alanlar \%89,5 dir. Raporda bünye, drenaj ve diğer özellikler hakkında bilgi bulunmamaktadır.

\section{Kireçsiz Kahverengi Orman Toprakları (KKO)}

KKO'lar, ilde \%0,5'lik (4.329 ha) bir alan kaplamaktadır. Eğim yönünden KKO'lar sırasıyla; düz ve düze yakın araziler (8.922 da) \%20,5, hafif eğimli araziler (19.368 da) $\% 44,7$ ve orta eğimli araziler ise \%34,7 (15.006 da) dir. KKO'larin \%55,3'ünü $(23.938$ da $)$ derin topraklar oluşturmaktadır. Orta derinlikte topraklar \%39,3 (17.027 da) ve sı̆̆ toprakların oranı ise \%5,4 (2.330 da) tür. KKO'larin \%60'1 (25.960 da) hiç veya çok az erozyona maruz kalırken, \%40'1 ise (17336 da) orta şiddetli erozyona maruz kalmıştır. Çalışmanın yapıldığı tarihte KKO olarak belirlenen alanların \%86,7'sinde (37.542 da) nadaslı kuru tarım yapılırken, \%13,3'ünde ise (5.754 da) sulu tarım yapılmaktadır. Besin elementi düzeyleri değerlendirildiğinde ise toprakların azot düzeyleri bakımından; $\% 57,5$ 'i orta ve $\% 38$ 'i ise yüksek düzeydedir. Alınabilir fosfor, alanın \%22,5'inde yetersiz, \%17,52'sinde orta ve $\% 55$ 'inde yüksek düzeydedir. $\mathrm{K}$ ise alanı \%95,3'ünde yüksek düzeydedir. Besin element düzeyine ilişkin alanın yaklaşık \%4,5'inde herhangi bir bilgi bulunmamaktadır. $\mathrm{Bu}$ toprakların \%83'ünde $\mathrm{pH}$ nötr seviyesinde iken, \%17'sinde ise hafif asidiktir. AYS'ye göre; I. Sınıf araziler \%20,5 (8.922 da), II. Sinıf araziler $\% 44,5$ (19.368 da) ve III. Sinıf araziler ise \%34,5'lik (15.006 da) bir alan kaplamaktır. Arazi yetenek alt sinıfları değerlendirildiğinde; sadece eğim ile ilgili problemi bulunan alanlar \%74, hem eğim hem de toprak açısından sorumlu alanlar \%5,5 dir. Raporda bünye, drenaj ve diğer özellikler hakkında bilgi bulunmamaktadır.

\section{İslenmeyen Araziler}

İşlenmeyen araziler, il arazi varlığı verilerine bağlı olarak çalışma alanın \%66,84'lük (582.065 ha) bir alanını kaplamaktadır. $\mathrm{Bu}$ araziler, ilin topoğrafik yapısından kaynaklı, yüksek rakımlı ve genellikle dik- çok dik eğimli arazilerden oluşmaktadır. Eğim ve yükseltiye bağlı olarak genellikle tarımsal amaçlara uygun olmadığından kullanılmamaktadır.

\section{Muş ili Arazi Özellikleri}

Arazinin eğimi, arazi kullanımını ve erozyonu etkileyen en önemli arazi karakteristiklerinden birisidir. Muş ili sahip olduğu ovaları bakımından önemli düz ve düze yakın arazileri barındırmasına karşın, mevcut topoğrafik yapısı nedeniyle çeşitli eğim sınıflarına da sahiptir. Buna göre; arazilerin \%9,3'ü düz ve düze yakın araziler, \%5,7'si hafif eğimli, \%12,8'i orta ve dik eğimli, $\% 0,4$ 'ü ise sarp ve çok dik eğimli arazilerden oluşmaktadır. Ancak, arazilerin yaklaşık \%68'i işlenmeyen dik eğimli arazileri ifade etmektedir (Şekil 5). 


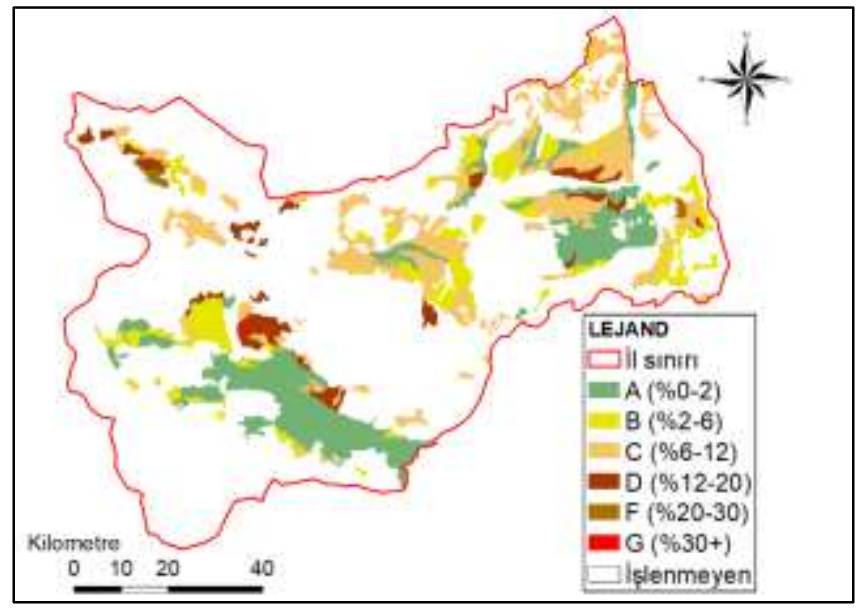

Şekil 5. Muş ili arazi eğim haritası

Eğimle birlikte araziler üzerinde en önemli olumsuz etken toprak erozyonudur. Erozyon kimi zaman eğime bağlı olarak doğal, kimi zamanda insan etkisiyle hızlandırılmış bir şekilde gerçekleşebilmektedir. Buna göre arazinin \%13'ünde erozyon tehlikesi bulunmamaktadır. \%13,3'ünde orta düzeyde, yaklaşık \%2'sinde ise şiddetli ve çok şiddetli düzeyde erozyon tehlikesi görülmektedir. Ancak, raporda işlenmeyen olarak tanımlanan arazilerin dik eğimli olduğu ve bundan dolayı erozyon risk potansiyeli taşıdığ unutulmamalıdır. Erozyon tehlikesi bulunmayan araziler düz- düze yakın ova kısımlarında iken, yüksek erozyonun görüldüğü araziler ise bitki örtüsü ile kaplı olmayan eğimli arazileri ifade etmektedir (Şekil 6).

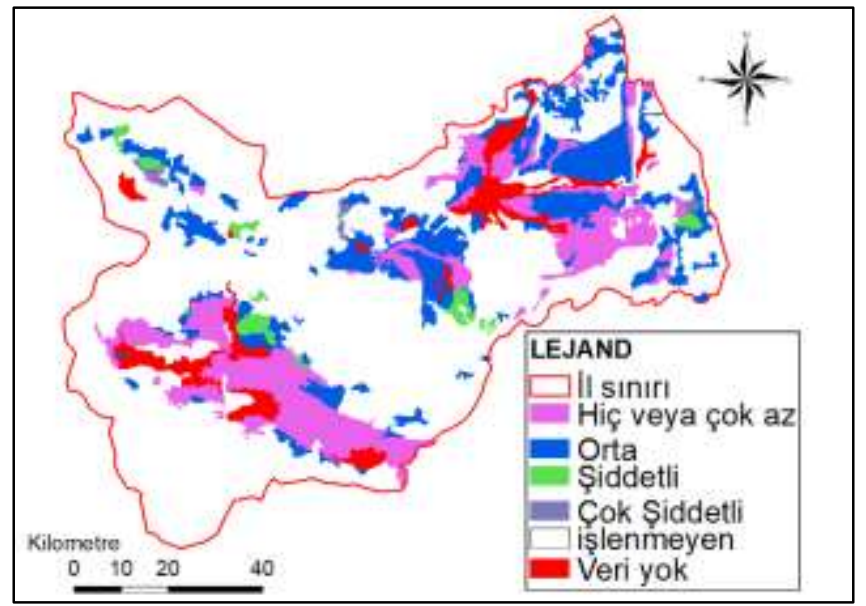

Şekil 6. Muş ili arazi erozyon haritası

Arazi yetenek sınıflaması, arazilerin değerlendirme, arazi kullanımlarının oluşturulmasında, sulu tarıma uygunluk sınıflaması ve toprakların mühendislik özelliklerinin değerlendirilmesi gibi birçok konuda arazilerin nasıl ve hangi amaçlarla kullanılacağını ve daha sonraki kullanımlar için nasıl korunması gerektiği ile ilgili yapılan bir sınıflamadır (Dinç ve Şenol, 2001). Bu sınıflamada tarımsal açıdan en iyi araziler I. Sınıf, en kötü araziler ise VIII. Sınıf olarak tanımlanmaktadır. Muş ili arazi varlığına bakıldığında; I. Sınıf seçkin araziler, tüm arazi varlığının yalnızca \%4'üne tekabül etmektedir. Arazilerin yaklaşık \%14'ü II. Sınıf, \%10'u III. sınıf arazilerdir. İşlenmeyen araziler ile birlikte, işlemeli (makinalı) tarıma uygun olmayan araziler ise tüm arazi varlığının yaklaşık \%69'unu oluşturmaktadır (Şekil 7).

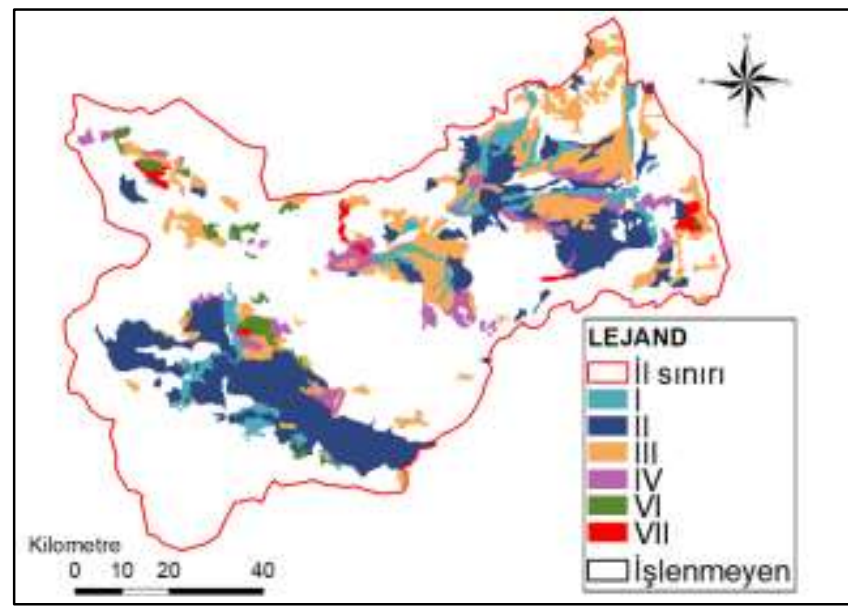

Şekil 7. Muş ili arazi yetenek sınıfları haritası

Toprakların bitki besin element düzeyleri değerlendirildiğinde; raporda yalnızca azot, alınabilir fosfor ve alınabilir potasyum ele alındığı ve bu besin elementlerine ait miktarları yerine "az", "orta", "yüksek" şeklinde sınıflandırıldığı görülmektedir. Azot bakımından çalışma alanın \%10'u az, \%15,6'sı orta ve yaklaşık \%7'si ise yüksek düzeydedir. Alınabilir fosfor bakımından çalışma alanın yaklaşık \%22'si az, \%8'i orta ve \%2,5'i yüksek düzeydedir. Yarayışlı potasyum bakımından ise çalışma alanın \%32,5'i yüksek düzeydedir. Toplam çalışma alanın yaklaşık \%68'inde ise ilgili besin elementleri bakımından herhangi bir veri bulunmamaktadır. CBS ortamında oluşturulmuş $\mathrm{N}, \mathrm{P}, \mathrm{K}$ haritaları şekil 8,9 ve 10 'da verilmiştir.

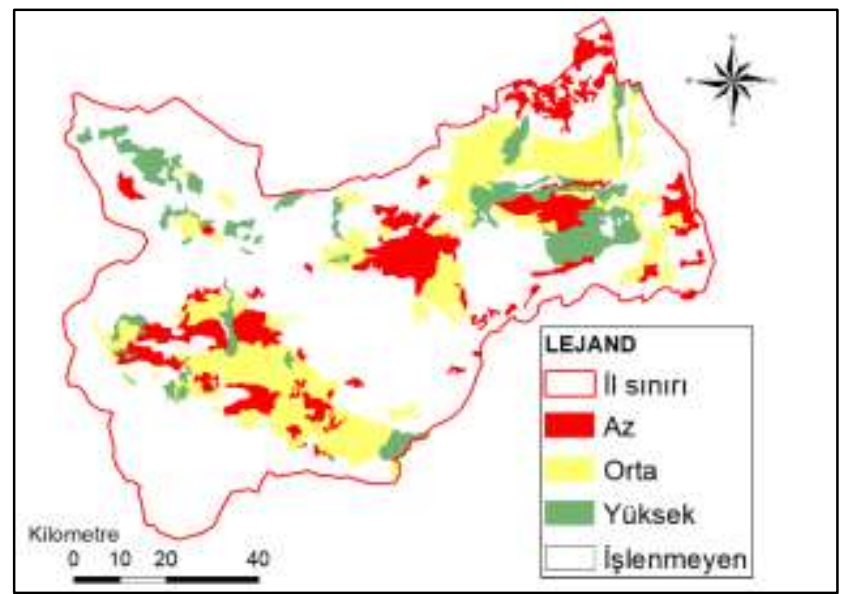

Şekil 8. Toprakların azot (N) düzeyi haritası

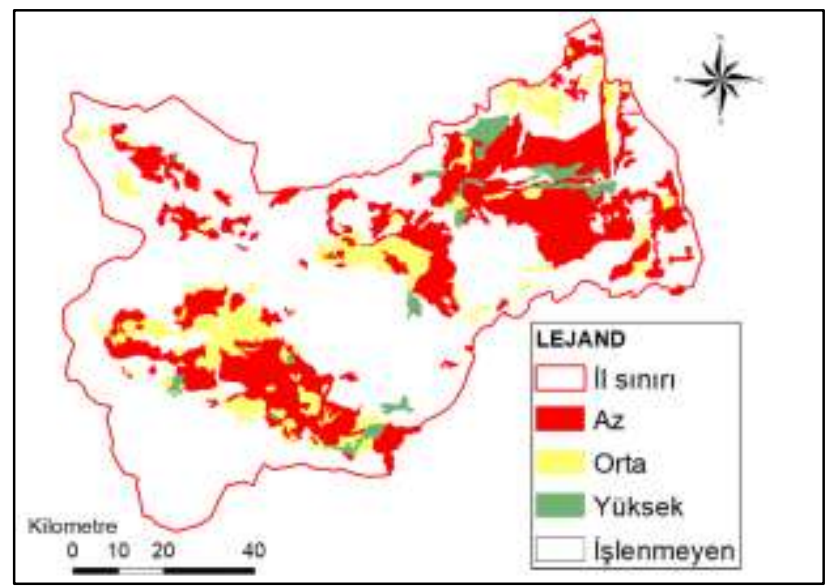

Şekil 9. Toprakların alınabilir fosfor düzeyi haritası 


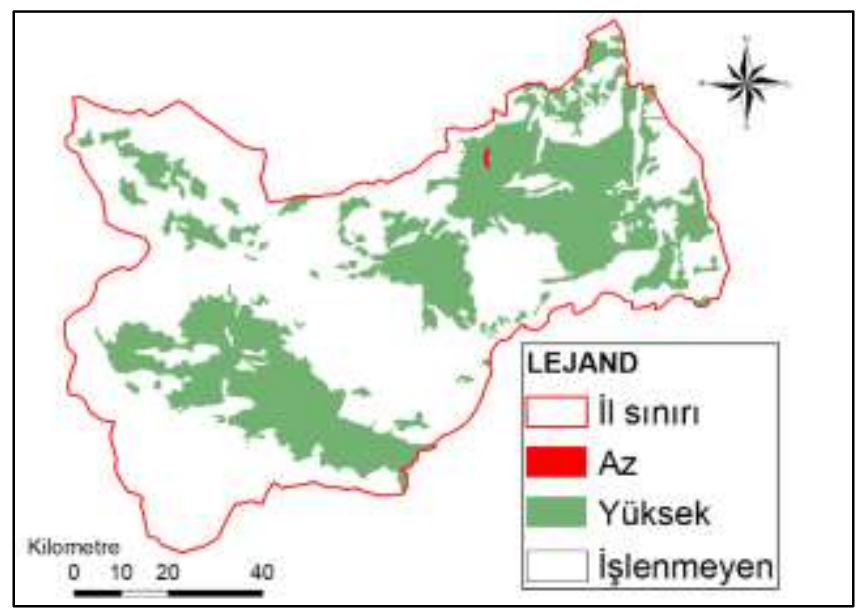

Şekil 10. Toprakların yarayışlı potasyum düzeyi haritası

\subsection{Muş Ovası Arazi Özellikleri ve Haritaları}

Muş ilinde bulunan 4 ovanın en büyüğü konumunda olan Muş Ovası genel olarak tarımsal anlamda önemli bir yere sahiptir. İlden ayrı olarak Muş Ovası bu başlıkta ayrıca ele alınmış ve CBS ortamında mevcut özellikleri ortaya konmuştur. Ovada en fazla VT'ler dağılım göstermektedir (Şekil 11). Bu topraklar iklimsel olarak kuru dönemlerde çatlama özelliğindedir. Yağışın veya sulamanın olduğu dönemlerde bu çatlaklar kendiliğinden kaybolmaktadır. 42.582 ha arazide (Ovanın yaklaşık \%40'1) yayılım gösteren VT'lerin hemen hemen tamamı düz-düze yakın arazilerdedir. Derin topraklar olup, erozyon sorunu bulunmamaktadır. VT'ler yüksek düzeyde kil içermekte olup, ağır topraklar olarak adlandırılmaktadır. VT'lerdeki en önemli sorunlardan birisi de tuzluluktur. Raporda hafif tuzlu olarak tanımlanmış olan araziler 28.608 ha olup, toplam VT'lerin yaklaşık \%60'ına tekabül etmektedir (Şekil 12). Hafif düzeydeki tuzluluk yalnızca tuzluluğa hassas bitkilerde sorun yaratabilmektedir. $\mathrm{Bu}$ tuzluluk düzeyi ileriki süreçte dikkat edilmesi gereken hususlardan birisidir.

Ovada önemli yayılıma sahip AT'ler ise Murat Nehri ve kollarının oluşumlarıdır. İnceden kabaya değişen tekstüre sahip bu topraklarda çok az da olsa yetersiz ve kötü drenaj şartları da mevcuttur. I, II ve III. Sınıf arazilere sahip bu topraklar, genellikle orta düzeyde $\mathrm{pH}$ 'ya sahiptir.

Ovada en az dağılım gösteren topraklar ise BT'lerdir. Yalnızca 14 ha. alanda yayılım gösteren sı̆̆ topraklar olup, Ovada yalnızca çok küçük bir bölgede yer almaktadır. İl genelinde önemli düzeyde yayılım gösteren Kahverengi Orman Toprakları ise ovada bulunmamaktadır.

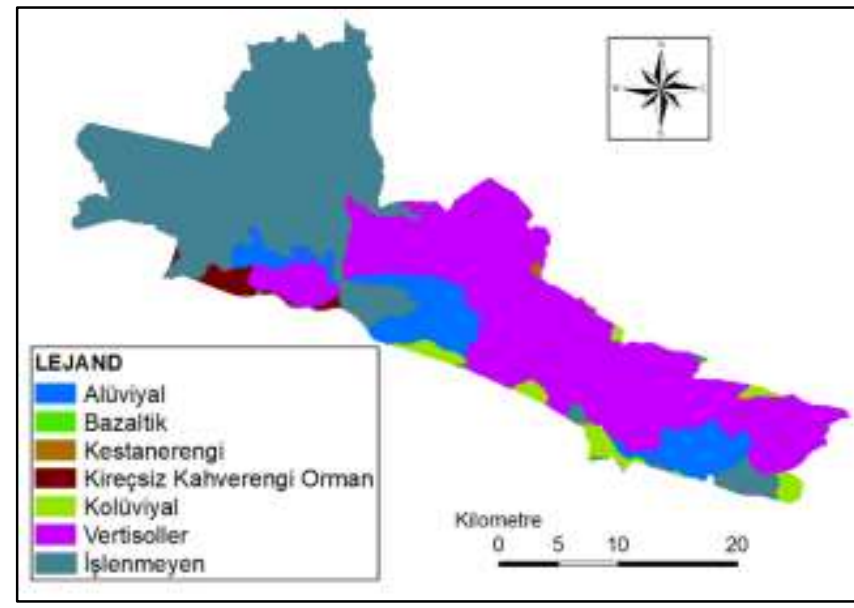

Şekil 11. Muş Ovası Büyük Toprak Grubu haritası

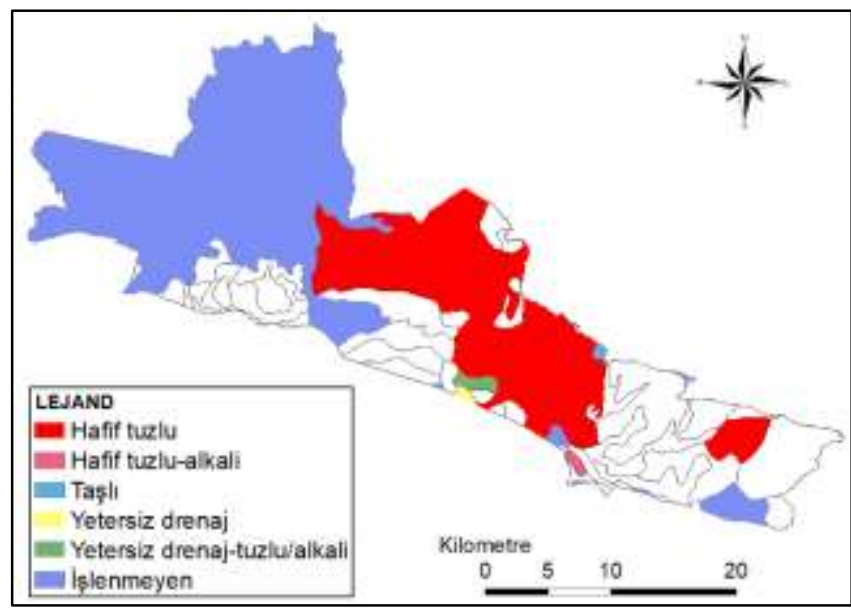

Şekil 12. Muş Ovası toprakları tuzluluk haritası

Eğim bakımından Ovanın hemen hemen tamamı düz-düze yakın arazilerden oluşmaktadır (Şekil 13). Buna karşın Ovanın kenar kısımlarında çok az yayılım gösteren D ve G eğime sahip araziler de bulunmaktadır. $G$ eğimli araziler aynı zamanda çok sığ topraklardır. Ancak bu araziler ihmal edilecek kadar çok küçük düzeyde kalmaktadır. Ova arazilerinin en büyük problemi olarak tuzluluk görülmektedir. Bu tuzluluk hafif düzeyde olup, arazilerin hemen hemen yarısına yakın kısminda bu sorun mevcuttur.

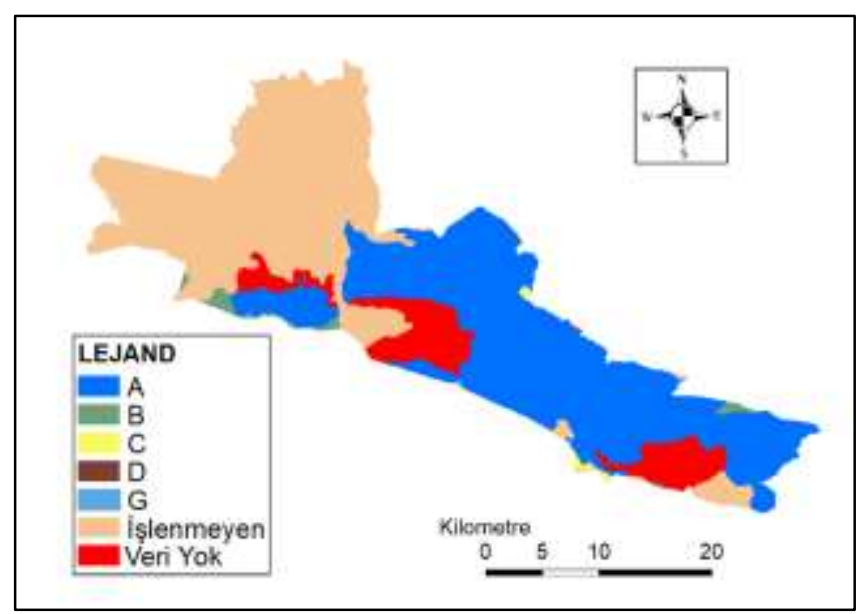

Şekil 13. Muş Ovası arazileri eğim haritası

Ovanın hemen hemen tamamında arazi kullanımı nadaslı kuru tarımdır. Arazinin 61.558 ha' 1 nadaslı kuru tarımda iken, yalnızca 3.764 ha'1 sulu tarım şeklinde kullanılmaktadır. Ancak önümüzdeki kısa dönemde 
yapılması tamamlanacak olan Alparslan-2 Barajı ile arazinin önemli bir kısmının sulamaya açılması beklenmektedir.

Ova topraklarının besin elementi düzeylerine bakıldığında ise, Azot bakımından toprakların 19.615 ha'ında az, 42.136 ha'ında orta ve 7.324 ha'ında ise yüksek düzeyde azot belirlenmiştir. Alınabilir fosfor ise, 44.379 ha'ında az, 21.384 ha'ında orta ve 3.312 ha'ında ise yüksek düzeydedir. Alınabilir potasyum bakımından ise ova topraklarının tamamı yüksek düzeydedir.

Ova topraklarının tamamında işlenmeyen olarak tanımlanmış olan araziler için herhangi bir veri bulunmamaktadir.

Muş Ovasının kimi özelliklerinin birlikte belirlendiği özellikler tablo 2'de verilmektedir. Ovanın genel özelliklerine bakıldığında VT'lerin önemli bir kısmının düze yakın eğime sahip arazilerde yayıldı ğı görülmektedir. Derin topraklara sahip VT'lerde erozyon riski de düşük düzeydedir. Buna karşın BT'ler ise genellikle C eğime sahip ve sığ topraklar olduğu görülmektedir. Büyük Toprak Grubu düzeyinde tanımlanan toprakların hemen hemen tamamı ince bünyeye sahiptir. Kil tekstür olarak adlandırılan bu bünye kimyasal verimliliğinin yüksek olmasına karşın, su tutma kapasitesinin yüksek oluşu nedeniyle kimi dönemlerde havalanma ile ilgili olumsuzlukları da barındırmaktadır. Ovanın önemli akarsu kaynakları tarafından genel özellikleri şekillenen AT'lerde ince tekstüre sahip olup, drenajları genellikle iyi düzeydedir. Ovada yer alan KT'ler ise genellikle B eğimine sahip arazilerde yayılım göstermektedir. Çizelgede yer almayan bilgilere raporda da yer verilmediğinden dolayı boş bırakılmıştır.

Tablo 2. Muş Ovası topraklarının BTG düzeyinde kimi toprak/arazi özelliklerinin değerlendirilmesi

\begin{tabular}{|c|c|c|c|c|c|c|}
\hline Büyük Toprak Grubu & $\begin{array}{c}\text { Toplam } \\
\text { Alan(ha) } \\
\end{array}$ & $\begin{array}{c}\text { Eğim (ha) } \\
\text { ve Sınıfı }\end{array}$ & $\begin{array}{c}\text { Toprak Derinlik } \\
\text { (ha)-Sınıf }\end{array}$ & $\begin{array}{c}\text { Bünye (ha) - } \\
\text { Sınıf }\end{array}$ & $\begin{array}{l}\text { Drenaj (ha) - } \\
\text { Sinıf }\end{array}$ & $\begin{array}{c}\text { Erozyon (ha) } \\
\text { Sinıf } \\
\end{array}$ \\
\hline VT & 42.582 & $4.581-\mathrm{B}$ & 36.028 -Derin & - & & $42.582-\mathrm{Az}$ \\
\hline İşlenmeyen & 39.354 & - & - & - & - & - \\
\hline AT & 17.195 & - & - & 9.102 - İnce & 8.286 - İyi & - \\
\hline KT & 6.246 & $4.065-\mathrm{B}$ & 3.800- Derin & - & - & $4.579-\mathrm{Az}$ \\
\hline KO & 2.476 & $1.980-\mathrm{A}$ & 1.293-Derin & 925- İnce & - & $1.980-\mathrm{Az}$ \\
\hline KKO & 1.117 & $674-\mathrm{A}$ & 461- Derin & - & - & $1.050-\mathrm{Az}$ \\
\hline BT & 14 & $14-\mathrm{C}$ & $14-\mathrm{S} 1 \breve{g}$ & - & - & 14- Orta \\
\hline Toplam & 108.984 & 11.314 & 41.596 & 10.027 & 8.286 & 50.205 \\
\hline
\end{tabular}

\section{Sonuç ve Öneriler}

Türkiye'nin önemli büyük ovalarından biri olan Muş Ovası'nı da içerisinde barındıran Muş ili toprakları ve arazilerinin genel özellikleri bakımından değerlendirildiği bu çalışmada, topraklar BTG düzeyinde ele alınmıştır. BTG düzeyinde en fazla dağılım gösteren topraklar KT'lerdir. En az dağılım gösteren topraklar ise; KKT, R ve BT'lerdir. Muş ili arazileri, ovalar hariç genellikle orta eğimli arazilerden oluşmaktadır. Ovalar hariç, arazilerin \%15'inde erozyon tehlikesi bulunmaktadır. Arazilerin \%28'i işlemeli tarıma elverişlidir. Besin elementi bakımından arazilerin neredeyse tamamında alınabilir potasyum yüksek seviyededir. Alınabilir fosfor bakımından toprakların $\% 22$ 'si, azot bakımından ise $\% 10$ 'u yetersiz düzeydedir. Bu besin elementleri dișında raporda herhangi bir başka besin elementi ile ilgili bilgi bulunmamaktadır. Her ne kadar bu üç besin elementi en fazla kullanılan besin elementlerini oluşturuyor olsa da, toprakların tüm potansiyellerinin belirlenmesi açısından diğer tüm makro ve mikro besin element düzeylerinin de sonraki yapılacak çalışmalarla belirlenmesi gerekmektedir.

Ancak bu çalışmada elde edilen verilerin, Muş ilinin tamamı için geçerli olduğu söylenemez. Çünkü, çalışmada ana kaynak olarak kullanılan raporda Muş İl'inin yaklaşık \%67'si hakkında herhangi bir bilgi bulunmamaktadır. Bu alanları olușturulan tüm alanlarda renklendirme yapılmamış; beyaz olarak bırakılmıştır. Göreceli olarak bu düzey yüksek gibi görünse de, Ova dışında kalan eğimli araziler İl yüzölçümünün önemli bir alanını kapladığından dolayı aslında bu çalışmada elde edilen verilerin önemli bir kısmı İldeki ovaların genel karakteristiklerini yansitmaktadir.

$\mathrm{Bu}$ çalışmada elde edilen veriler ve üretilen haritalar, Muş ilin'de yer alan Muş, Bulanık, Malazgirt ve Liz Ovaları'nın tarımsal potansiyelini de ortaya çıkarmıştır. CBS ortamında üretilen haritalarda ovaların tarımsal potansiyelleri yüksek, düz ve derin topraklardan oluştuğu görülmektedir. Ancak, raporda yer alan bilgiler ile söz konusu ovaların tarımsal potansiyeli tam olarak ortaya konulamamaktadır. Bundan dolayı, İl sınırları içerisinde yer alan ovalar başta olmak üzere, tarımsal potansiyeli yüksek arazilerin topraklarının detaylı bir şekilde ele alınması gerekmektedir.

İlin barındırdığı ovaların problemlerinin bir kısmı da bu çalışmayla ortaya konmuştur. Ovalar hariç arazilerin önemli bir kısmında eğim önemli bir problem olarak değerlendirilmiştir. Toprak derinliği kimi yerlerde bitkisel üretimi sınırlayıcı niteliktedir. Ova topraklarının bir kısmında özellikle VT'ler olarak adlandırılan topraklarda toprak tekstürünün yüksek düzeyde kil içermesinden dolayı bitkisel üretimde de çeşitli sorunlar olduğu değerlendirilmektedir. Ayrıca Muş Ovasında yer alan VT'lerde hafif tuzluluk problemi de mevcuttur. Tarımsal üretimi sınırlayan bu sorunların daha detaylı bir şekilde ele alınması gerekmektedir. Ancak bu çalışmada kullanılan mevcut raporda bu mümkün değildir. Türkiye'de tarımsal 
potansiyeli yüksek birçok ovanın toprakları detaylı bir şekilde incelenmiş ve haritalanmıştır. Ancak Muş ilindeki Ovalarda bu çalışma henüz hayata geçmemiştir. Uygun arazi kullanımı ve yönetiminin yanı sıra, ürünlerden optimum karlılık elde etmek amaciyla kullanılan toprakların korunması ve sürdürülebilmesi açısından detaylı toprak etüd ve arazi çalışmaları mutlak suretle yapılmalıdır. Bu çalışmalar neticesinde toprakların tüm özellikleri ortaya çıkarılmalı, potansiyellerine uygun kullanımları belirlenmeli, tarımsal potansiyeli düşük olan arazilerde yapılaşmaya izin verilmeli, tarımsal potansiyeli yüksek olan arazilerde ise tarım dişı maçlarla kullanıma kesinlikle izin verilmemelidir. Özellikle Türkiye'nin 3. Büyük ovası konumunda bulunan ve 2017 yılında resmi olarak da büyük ova konumuna erişen Muş Ovası topraklarının incelenmesi, tüm toprak özelliklerinin detaylı bir şekilde ortaya çıkarılması, mevcut yasalar 1şı̆̆ında (özellikle 5403 sayılı kanun) ele alınması önemli ve acil durumda olan çalışmalar içerisinde yer almalıdır.

\section{Kaynakça}

Anonim (1988). Muş ili Verimlilik Envanteri ve Gübre İhtiyaç Raporu. Tarım Orman ve Köyişleri Bakanlığ1- Köy Hizmetleri Genel Müdürlüğü yayınları. TOVEP Yayın no: 56. ANKARA

Anonim (2020a). Muş Valiliği resmi internet sitesi http://www.mus.gov.tr/cografi-yapi-mus

Anonim (2020b). Muş Tarım ve Orman İl Müdürlüğü Tanitım filmi. https://www.youtube.com/watch?v=EXnNfYSsjHk

Anonim 2018. Corine Land Cover (CLC) 2018, Version 2020_20u1, https://land.copernicus.eu/paneuropean/corine-land-cover/clc2018
Dinç, U., \& Şenol, S. (2001). Toprak Etüt ve Haritalama. Çukurova Üniversitesi Ziraat Fakültesi. Genel yayın no:161. Adana.

Dölek, İ. (2013). Muş'ta Yaşanan Sel ve Taşkınlara Neden Olan Doğal Faktörlerin Analizi. Marmara Coğrafya Dergisi, 28, 408-422.

Dölek, İ.,\& Avcı, V., (2017). Muş İlinin Sel ve Taşkın Duyarlılık Haritalarının Oluşturulması. The Journal of Academic Social Science, 5(44), 190-204.

Dölek, İ., Avcı, V., \& Harunoğulları, M. (2018). Nüfusun ve Yerleşmelerin Yükseltiye Göre Değişimi: Muş İli Örneği. Anemon Muş Alparslan Üniversitesi Sosyal Bilimler Dergisi, 6(6), 1011-1022.

Günek, H., Sunkar, M., \& Toprak, A., (2013). Muş Şehrini Etkileyen Çar ve Muş Derelerinin Bazı Jeomorfometrik İndislere Göre Analizleri. TMMOB Coğrafi Bilgi Sistemleri Kongresi, 11-13 Kasım, Ankara

Jenny, H. (1941) Factors of Soil Formation: A System of Quantitative Pedology. Dover Publications, New York, $281 \mathrm{p}$.

Kıranşan, K. (2017) Bulanık-Malazgirt Havzası'nın (Muş) Fiziki Coğrafyası- Doktora Tezi. Elazığ: Fırat Üniversitesi.

TÜİK, 2019. Türkiye İstatistik Kurumu, Merkezi dağıtım sistemi. İnternet erişim: https://biruni.tuik.gov.tr/medas/

Usul, M., \& Dengiz, O. (2010). Yarı Kurak İklim Koşulları Altında Farklı Fizyografya, Benzer Ana Materyal Üzerinde Yer alan Toprakların Pedogenesisleri. Toprak Su Dergisi, 2014, 3(2): 102-110. 